\title{
Mediasi Perbankan Dalam Penyelesaian Sengketa Perbankan Secara Sederhana, Cepat, dan Biaya Ringan
}

\author{
Noor Hafidah, M. Natsir Asnawi \\ Fakultas Hukum Universitas Lambung Mangkurat \\ hafidahnoor@gmail.com
}

\begin{abstract}
As an institution that is based on trust, banks must hold prudential principle in its operationalised because the funds managed by banks are public funds and Bank Indonesia as the holder of the monetary authorities have a major role in efforts to protect and ensure that public funds are collected in a state that is safe and the customer does not harmed as a result of bank error, especially in the dispute resolution between the bank and the bank or between banks and customers. Bank Indonesia efforts with the settlement of disputes in the banking escorted through Bank Indonesia Regulation Number 8/5 / PBI / 2006 dated January 30, 2006 and Bank Indonesia Circular Letter No. 8/14 / DPNP dated June 1, 2006 about Banking Mediation further that the issue of whether Regulation Bank Indonesia No. 8/5 / PBI / 2006 dated January 30, 2006 and Bank Indonesia Circular Letter No. 8/14 / DPNP dated June 1, 2006 on Banking Mediation already provides protection for banks and customers. It is based on several cases arise banking dispute settlement ends with an adverse outcome the customer. Therefore, this issue needs to be further elaborated in order to find common ground so that all the problems of the banking industry players both society in general and customers in particular banking institutions themselves can be protected comprehensively.
\end{abstract}

Keywords : mediation,resolution,dispute,customer

\begin{abstract}
Abstrak
Sebagai lembaga yang berlandaskan kepercayaan, perbankan dalam operasionalisasinya harus memegang prinsip kehati-hatian dikarenakan dana yang dikelola oleh bank adalah dana masyarakat dan Bank Indonesia selaku pemegang otoritas moneter mempunyai peran yang besar dalam upaya melindungi dan menjamin agar dana dana masyarakat yang terhimpun dalam keadaan yang aman dan nasabah tidak dirugikan akibat kesalahan bank, terutama dalam menyelesaikan sengketa yang terjadi antara bank dengan bank atau antara bank dengan nasabah. Upaya Bank Indonesia dalam kaitannya dengan penyelesaian sengketa perbankan di kawal melalui Peraturan Bank Indonesia Nomor 8/5/PBI/2006 tanggal 30 Januari 2006 dan Surat Edaran Bank Indonesia Nomor 8/14/DPNP tanggal 1 Juni 2006 tentang Mediasi Perbankan.Menjadi persoalan selanjutnya bahwa apakah Peraturan Bank Indonesia Nomor 8/5/PBI/2006 tanggal 30 Januari 2006 dan Surat Edaran Bank Indonesia Nomor 8/14/DPNP tanggal 1 Juni 2006 tentang Mediasi Perbankan sudah memberikan perlindungan bagi bank maupun nasabah. Hal ini mengemuka didasarkan pada beberapa kasus penyelesaian sengketa perbankan berakhir dengan hasil yang merugikan nasabah. Oleh karena itu permasalahan ini perlu dielaborasi lebih lanjut agar ditemukan titik temu permasalahan sehingga semua pelaku industri perbankan baik masyarakat secara umum dan nasabah pada khususnya juga lembaga perbankan itu sendiri dapat terlindungi secara komprehensif.
\end{abstract}

Kata Kunci; mediasi, penyelesaian, sengketa, nasabah 


\section{Pendahuluan}

Industri perbankan sebagai bagian dari Industri keuangan mempunyai karakteristik yang khusus sebagai lembaga keuangan. Karakteristik khusus tersebut tercermin dalam operasional perbankan yang memiliki fungsi Intermediary, yaitu menghimpun dan menyalurkan dana kepada masyarakat yang dilandasi oleh kepercayaan, serta layanan yang lebih kompleks yang meliputi pembiayaan makro, pembiayaan ekspor impor, transaksi derivatif, fasilitas pembayaran perdagangan internasional (letter of credit) dan lain sebagainya.

Layanan Perbankan yang sedemikian kompleks dalam prakteknya kadang kala bersentuhan dengan konflik atau sengketa. Sengketa dapat terjadi karena adanya perbedaan pendapat antara bank dengan nasabah mengenai kewajiban dan hak masing-masing, wanprestasi dari nasabah sebagai debitur, tindakan sepihak bank yang dianggap merugikan nasabah, dan sebagainya. Kenyataan demikian menuntut adanya pola penyelesaian sengketa yang efektif dan efisien.

Dalam konteks penyelesaian sengketa secara demikian, Bank Indonesia sebagai bank sentral yang memiliki kewenangan dalam menata aktivitas perbankan di Indonesia telah mengeluarkan beberapa peraturan yang terkait dengan mekanisme penyelesaian sengketa, antara lain Peraturan Bank Indonesia Nomor 8/5/PBI/2006 tanggal 30 Januari 2006 dan Surat Edaran Bank Indonesia Nomor 8/14/DPNP tanggal 1 Juni 2006 tentang Mediasi Perbankan.

Pasal 1 angka 5 Peraturan Bank Indonesia Nomor $\quad 8 / 5 / \mathrm{PBI} / 2006$ menyatakan bahwa mediasi merupakan proses penyelesaian sengketa yang melibatkan mediator untuk membantu para pihak yang bersengketa guna mencapai penyelesaian dalam bentuk kesepakatan sukarela terhadap sebagian ataupun seluruh permasalahan yang disengketakan.

Model penyelesaian mediasi bagi kalangan perbankan merupakan model yang dianggap tepat karena hubungan bank dan nasabah mengandung kerahasiaan. Kerahasiaan dimaksud adalah kerahasiaan bank sebagaimana tersebut di dalam Pasal 40 UU No. 10 Tahun 1998 tentang Perbankan. Penyelesaian secara mediasi juga menunjang upaya menemukan resolusiresolusi yang terbaik bagi kedua belah pihak. Selain itu mediasi dianggap mampu membuka ruang yang lebih luas bagi para pihak berperkara untuk menemukan solusi yang saling menguntungkan (win-win solution). 
Sekalipun demikian, pelaksanaan mediasi dalam prakteknya ada kalanya tidak memberikan hasil penyelesaian terbaik bagi kedua belah pihak. Deadlock atau kebuntuan mediasi sering terjadi karena tidak dapat didekatkannya perbedaan-perbedaan yang ada antar nasabah dan bank.

Bank Indonesia dalam hal ini telah menerbitkan Peraturan Bank Indonesia Nomor 8/5/PBI/2006 tentang Mediasi Perbankan. Peraturan ini pada dasarnya ingin menjadi payung hukum bagi pelaksanaan mediasi perbankan dalam menyelesaikan sengketa-sengketa yang timbul antara pihak bank dengan nasabah maupun antara bank dengan bank lainnya. Setiap peraturan memiliki kelebihan dan kekurangan. Hal yang paling sering dipermasalahkan adalah apakah suatu peraturan didasarkan pada bangunan pertimbangan yang matang dan memuat klausul-klausul yang diperlukan. Suatu peraturan juga sering dikritisi dari apakah ia mampu memberikan perlindungan secara berimbang kepada pihak-pihak yang terlibat dalam suatu persengketaan. Tulisan ini berupaya membahas hal tersebut dalam kerangkan perlindungan kepentingan bank dan nasabah dalam penyelesaian sengketa perbankan.

Berdasarkan uraian pada latar belakang tersebut, maka dirumuskan satu permasalahan, yaitu apakah Peraturan Bank Indonesia Nomor 8/5/PBI/2006 tentang Mediasi Perbankan telah memberikan perlindungan hukum yang cukup terhadap nasabah dan bank.

\section{Hasil Dan Pembahasan}

Substansi Peraturan Bank Indonesia
Nomor 8/5/PBI/2006 tentang Mediasi
Perbankan Peraturan Bank Indonesia Nomor 8/5/PBI/2006 tentang Mediasi Perbankan (PBI) merupakan peraturan yang ditetapkan oleh Gubernur Bank Indonesia pada tanggal 30 Januari 2006 yang telah diubah dengan Peraturan Bank Indonesia Nomor 10/1/PBI/2008 tentang Perubahan atas Peraturan Bank Indonesia Nomor 8/5/PBI/2006 tentang Mediasi Perbankan. Sekalipun telah diubah, namun substansi dari Peraturan Bank Indonesia Nomor 8/5/PBI/2006 tentang Mediasi Perbankan pada prinsipnya sama, karena perubahan terhadap PBI tersebut hanya mencakup pencabutan ketentuan Pasal 3 ayat (2) mengenai tenggat waktu pembentukan lembaga Mediasi Perbankan serta Pasal 15 mengenai alamat Direktorat Investigasi dan Mediasi Perbankan pada Bank Indonesia. Materi atau substansi pelaksanaan mediasi perbankan sama sekali tidak mengalami perubahan. Setidaknya, ada tiga hal yang mendasari dikeluarkannya PBI ini, yaitu: (a) fakta menunjukkan bahwa penyelesaian 
pengaduan nasabah oleh bank tidak selalu dapat memuaskan nasabah dan berpotensi menimbulkan sengketa di bidang perbankan antara nasabah dengan bank; (b) cara penyelesaian sengketa di bidang perbankan selama ini, baik melalui jalur litigasi maupun proses internal bank cenderung berlarutlarut dan berpotensi merugikan nasabah dan meningkatkan risiko reputasi bagi bank; (c) prinsip umum dalam penyelesaian sengketa perbankan adalah prinsip sederhana, cepat, biaya ringan, dan berbasis win-win solution, prinsip mana belum tergambar dan terwujud dalam cara penyelesaian melalui jalur litigasi maupun proses internal bank. Mediasi dalam hal ini dianggap sebagai cara penyelesaian yang mampu mewujudkan prinsip-prinsip tersebut.

Kewenangan pengawasan dan penyelesaian sengketa perbankan saat ini telah beralih kepada Otoritas Jasa Keuangan (OJK). Sejak Januari 2014, fungsi, tugas dan wewenang pengaturan dan pengawasan kegiatan mediasi perbankan dialihkan ke OJK. Untuk keperluan itu, OJK sudah menerbitkan sejumlah peraturan dan surat edaran, namun tidak secara tegas mencabut Peraturan Bank Indonesia yang mengatur masalah serupa sebelumnya (http://www.hukumonline.com/klinik/detail/ $\underline{\text { 1t53156814aa258/prosedur-mediasi- }}$ perbankan-di-era-otoritas-jasa-keuangan)

Beberapa peraturan yang telah diterbitkan OJK mengenai pelaksanaan mediasi perbankan adalah:

a. Peraturan OJK No. 1/POJK.07/2013

tentang Perlindungan Konsumen

Sektor Jasa Keuangan;

b. Peraturan OJK No. 1/POJK.07/2014 tentang Lembaga Alternatif Penyelesaian Sengketa; dan

$\begin{array}{lccr}\text { c. Surat Edaran } & \text { OJK } & \text { No. } \\ \text { 2/SEOJK.07/2014 } & \text { tanggal } & 14\end{array}$

Februari 2014 tentang Pelayanan dan

Penyelesaian Pengaduan Konsumen Pada Pelaku Usaha Jasa Keuangan.

Sekalipun kewenangan mediasi perbankan telah beralih kepada OJK, PBI mengenai mediasi perbankan masih tetap berlaku dan dapat dijadikan pedoman dalam penyelenggaraan mediasi perbankan. Dalam kerangka memaksimalkan mediasi perbankan guna mewujudkan penyelesaian sengketa yang sederhana, cepat, biaya ringan, dan win-win solution, PBI ini memuat beberapa hal pokok meliputi penyelenggaraan mediasi, proses beracara, dan adekuasi peraturan ini.

Penyelenggaraan mediasi perbankan ditujukan terhadap Sengketa antara Nasabah dengan Bank yang disebabkan tidak dipenuhinya tuntutan finansial Nasabah oleh Bank dalam penyelesaian pengaduan Nasabah. Penyelenggaraan 
mediasi perbankan mengikuti beberapa ketentuan, yaitu:

1) Mediasi di bidang perbankan dilakukan oleh lembaga Mediasi perbankan independen yang dibentuk asosiasi perbankan;

2) Dalam pelaksanaan tugasnya, lembaga Mediasi perbankan independen melakukan koordinasi dengan Bank Indonesia;

3) Sepanjang lembaga Mediasi perbankan independen belum dibentuk, fungsi Mediasi perbankan dilaksanakan oleh Bank Indonesia;

4) Fungsi mediasi perbankan yang dilaksanakan oleh Bank Indonesia terbatas pada upaya membantu nasabah dan Bank untuk mengkaji ulang sengketa secara mendasar dalam rangka memperoleh kesepakatan;

5) Pelaksanaan mediasi perbankan difasilitasi oleh seorang Mediator yang memiliki kualifikasi berikut:

a) Memiliki pengetahuan di bidang perbankan, keuangan, dan atau hukum;

b) Tidak mempunyai kepentingan finansial atau kepentingan lain atas penyelesaian sengketa; dan

c) Tidak memiliki hubungan sedarah atau semenda sampai dengan derajat kedua dengan nasabah atau perwakilan nasabah dan Bank.
6) Mediasi perbankan dilaksanakan untuk setiap sengketa yang memiliki nilai tuntutan finansial paling banyak Rp500.000.000,00 (lima ratus juta rupiah). Dikecualikan dari hal ini adalah tuntutan finansial nasabah yang diakibatkan oleh kerugian immaterial.

Sebagaimana proses mediasi pada umumnya, maka pengajuan penyelesaian dalam rangka mediasi perbankan kepada Bank Indonesia dilakukan oleh nasabah atau perwakilan nasabah. Dalam hal Nasabah atau Perwakilan Nasabah mengajukan penyelesaian sengketa kepada Bank Indonesia, Bank wajib memenuhi panggilan Bank Indonesia. Pengajuan sengketa diajukan secara tertulis dengan disertai dokumen pendukung yang memadai; pernah diajukan upaya penyelesaiannya oleh nasabah kepada Bank.Sengketa yang diajukan tidak sedang dalam proses atau belum pernah diputus oleh lembaga arbitrase atau peradilan, atau belum terdapat kesepakatan yang difasilitasi oleh lembaga Mediasi lainnya. Sengketa yang diajukan merupakan sengketa keperdataan dan sengketa yang diajukan belum pernah diproses dalam Mediasi perbankan yang difasilitasi oleh Bank Indonesia. Pengajuan penyelesaian Sengketa tidak melebihi 60 (enam 
puluh) hari kerja sejak tanggal surat hasil penyelesaian Pengaduan yang disampaikan Bank kepada Nasabah.

Proses Mediasi dilaksanakan setelah nasabah atau perwakilan nasabah dan Bank menandatangani perjanjian mediasi (agreement to mediate) yang memuat kesepakatan untuk memilih mediasi sebagai alternatif penyelesaian sengketa dan persetujuan untuk patuh dan tunduk pada aturan mediasi yang ditetapkan oleh Bank Indonesia. Bank wajib mengikuti dan mentaati perjanjian Mediasi yang telah ditandatangani oleh Nasabah atau Perwakilan Nasabah dan Bank. Namun demikian, Nasabah dan Bank dapat memberikan kuasa kepada pihak lain dalam proses mediasi melalui surat kuasa khusus yang paling sedikit mencantumkan kewenangan penerima kuasa untuk mengambil keputusan.

Pelaksanaan proses Mediasi sampai dengan ditandatanganinya Akta Kesepakatan dilakukan dalam jangka waktu paling lama 30 (tiga puluh) hari kerja sejak nasabah atau perwakilan nasabah dan Bank menandatangani perjanjian Mediasi (agreement to mediate). Jangka waktu proses Mediasi dapat diperpanjang sampai dengan 30 (tiga puluh) hari kerja berikutnya berdasarkan kesepakatan nasabah atau perwakilan nasabah dan Bank.
Kesepakatan antara nasabah atau perwakilan nasabah dengan Bank yang dihasilkan dari proses mediasi dituangkan dalam Akta Kesepakatan yang ditandatangani oleh nasabah atau perwakilan nasabah dan Bank. Bank wajib melaksanakan hasil penyelesaian sengketa perbankan antara nasabah dengan Bank yang telah disepakati dan dituangkan dalam Akta Kesepakatan. Jika bank melanggar ketentuan mengenai mediasi, maka dikenakan sanksi administratif sesuai Pasal 52 Undang-Undang Nomor 7 Tahun 1992 tentang Perbankan sebagaimana telah diubah dengan Undang-Undang Nomor 10 Tahun 1998, berupa teguran tertulis dan dapat diperhitungkan dalam komponen penilaian tingkat kesehatan Bank.

\section{Adekuasi PBI dalam Memberikan Perlindungan terhadap Bank dan Nasabah}

Pengaturan mengenai mediasi perbankan dalam PBI tersebut di atas pada prinsipnya bertujuan untuk mewujudkan suatu mekanisme penyelesaian sengketa perbankan secara efisien dan efektif berdasar pada asas sederhana, cepat, dan biaya ringan. Ditetapkannya mediasi sebagai cara penyelesaian sengketa perbankan juga didasarkan pada sifat mediasi yang lebih fleksibel dan menekankan pada cara 
penyelesaian yang saling menguntungkan antara bank dengan nasabah.

PBI karenanya dipandang sebagai upaya melindungi kepentingan bank dan nasabah yang terlibat sengketa perbankan. Kepentingan yang ingin dilindungi adalah kepentingan berkaitan efisiensi waktu, menjaga reputasi bank dan nasabah, serta memelihara hak-hak bank dan nasabah karena cara penyelesaian yang dikehendaki adalah win-win solution.

Menurut kami, PBI ini sudah memberikan perlindungan hukum terhadap bank dan nasabah secara proporsional dengan beberapa alasan. Pertama, PBI menekankan kepada Bank sebagai pihak yang pada umumnya lebih dominan untuk tunduk dan patuh melaksanakan kesepakatan yang tertuang dalam akta kesepakatan dengan ancaman sanksi administratif yang dapat diakumulasikan dalam penilaian kesehatan bank. PBI ini tampaknya menyadari posisi dominan bank dan kecenderungan nasabah sebagai pihak yang lebih inferior dengan menekankan kewajiban Bank menaati akta kesepakatan. Kedua, PBI yang menekankan penerapan mediasi perbankan dalam penyelesaian sengketa perbankan antara nasabah dan bank mengandung makna menjaga kredibilitas bank dan image bank di mata publik. Ini dikarenakan sifat mediasi yang rahasia atau tertutup memungkinkan reputasi bank tetap dapat terjaga. Jika pun dalam akta kesepakatan Bank memiliki sejumlah kewajiban tertentu kepada nasabah, pelaksanaannya bersifat internal dan tidak terkuak ke publik.

\section{Simpulan}

Berdasarkan uraian tersebut, dapat disimpulkan bahwa Peraturan Bank Indonesia Nomor 8/5/PBI/2006 tentang Mediasi Perbankan telah diubah dengan Peraturan Bank Indonesia Nomor 10/1/PBI/2008 tentang Perubahan atas Peraturan Bank Indonesia Nomor 8/5/PBI/2006 tentang Mediasi Perbankan pada prinsipnya telah memberikan perlindungan secara proporsional kepada bank dan nasabah. PBI tersebut menekankan adanya keseimbangan kedudukan antara bank dan nasabah dalam penyelesaian sengketa perbankan.

\section{Daftar Pustaka} Peraturan Bank Indonesia Nomor 8/5/PBI/2006 tentang Mediasi Perbankan.

Peraturan Bank Indonesia Nomor 10/1/PBI/2008 tentang Perubahan atas Peraturan Bank Indonesia 
Nomor 8/5/PBI/2006 tentang Mediasi Perbankan.

"Prosedur Mediasi Perbankan di Era Otoritas Jasa Keuangan" http://www.hukumonline.com/klin $\underline{\mathrm{ik} / \mathrm{detail} / \mathrm{lt} 53156814 \mathrm{aa} 258 / \mathrm{prosedu}}$ r-mediasi-perbankan-di-eraotoritas-jasa-keuangan, diakses tanggal 2 November 2016. 